\title{
Natural resource-based industries and prostate cancer risk in Northeastern Ontario: A case-control study
}

\author{
Jeavana Sritharan, Paul A. Demers, Shelley A. Harris, \\ Donald C. Cole, Nancy Kreiger, Andrea Sass-Kortsak, and \\ Nancy Lightfoot
}

\begin{abstract}
Version Post-Print/Accepted Manuscript
Citation Sritharan J*, Demers PA, Harris SA, Cole DC, Kreiger N, Sass-Kortsak (published version) A, Lightfoot N. Natural resource based industries and prostate cancer risk in northeastern Ontario: a case control study. Accepted for publication in Occupational and Environmental Medicine, April 2016.

Publisher's Statement This article has been accepted for publication in the journal of Occupational and Environmental Medicine following peer review. The definitive copyedited, typeset version Sritharan J, Demers PA, Harris SA, et al. Occup Environ Med 2016;73:506-511 is available online at: https://dx.doi.org/10.1136/oemed-2016-103573.
\end{abstract}

How to cite TSpace items

Always cite the published version, so the author(s) will receive recognition through services that track citation counts, e.g. Scopus. If you need to cite the page number of the TSpace version (original manuscript or accepted manuscript) because you cannot access the published version, then cite the TSpace version in addition to the published version using the permanent URI (handle) found on the record page. 


\section{Natural resource based industries and prostate cancer risk in northeastern Ontario: a case-control study}

\section{Corresponding Author:}

Jeavana Sritharan, PhD Student

Institute of Medical Science, University of Toronto

Occupational Cancer Research Centre, Cancer Care Ontario

525-03-327 University Avenue

Toronto, Ontario, Canada M5G 2L3

jeavana.sritharan@occupationalcancer.ca

Tel: (416) 971-9800 x 2680

Dr. Paul A. Demers

Director, Occupational Cancer Research Centre, Cancer Care Ontario

Professor, University of Toronto

Dr. Shelley A. Harris

Scientist, Cancer Care Ontario

Associate Professor, University of Toronto

Dr. Donald C. Cole

Professor, University of Toronto

Dr. Nancy Kreiger

Professor, University of Toronto

Dr. Andrea Sass-Kortsak

Associate Professor, University of Toronto

Dr. Nancy Lightfoot

Associate Professor, School of Rural and Northern Health, Laurentian University

Key Words: occupational exposure; natural resource industries; prostate cancer

Word Count: 3,319 


\section{What this paper adds}

- Exogenous factors may play a role in the etiology of prostate cancer, but there are still no wellestablished risks

- In previous studies, occupational exposures that have been evaluated in relation to prostate cancer resulted in mixed findings and many of these occupational exposures are found in natural resource based industry work

- In this study, elevated risks were observed for employment in forestry and logging industries, wood product industries, and paper and allied products industries and risks increased with $\geq 10$ years duration of employment

- To further evaluate associations observed in this study, additional work should focus on natural resource based industry exposures in occupational groups 


\section{ABSTRACT}

Objective Prostate cancer continues to be the most commonly diagnosed cancer in men, and there is limited knowledge on preventable risk factors. A number of occupational exposures in natural resource based industries are suspected to be related to prostate cancer risk. This study investigates associations between employment in these industries and prostate cancer.

Methods Data were from a population-based, case-control study previously conducted in Northeastern Ontario. Incident cases ( $N=760$ ) aged 45-85 years who were diagnosed between 1995 and 1998 were identified from the Ontario Cancer Registry. Controls ( $N=1632)$ were recruited using telephone listings and were frequency-matched to cases by age. Lifetime occupational history was collected for all participants. Logistic regression was used to estimate odds ratios (OR) and their associated 95\% confidence internals $(\mathrm{Cl})$.

Results Elevated risks were observed for employment in forestry and logging industries (OR=1.87, 95\% $\mathrm{Cl}=1.32-2.73$ and occupations $(\mathrm{OR}=1.71,95 \% \mathrm{Cl}=1.24-2.35)$, and these risks increased with duration of employment for $\geq 10$ years. Elevated risks were also found for employment in wood products industries $(\mathrm{OR}=1.45,95 \% \mathrm{Cl}=1.07-1.97)$ and paper and allied products industries $(\mathrm{OR}=1.43,95 \% \mathrm{Cl}=1.03-2.00)$ and when duration of employment was $\geq 10$ years. There were also elevated risks in agriculture and mining related work, however these findings were not consistent across industry and occupation categories. Conclusions Prostate cancer risk may be associated with work in several natural resource industries, primarily in the forest industries. To further evaluate observed associations, studies should focus on natural resource based exposures in larger populations with improved exposure assessment. 


\section{INTRODUCTION}

Prostate cancer is the most commonly diagnosed cancer in North American and European men. ${ }^{1-2}$ The risk factors for prostate cancer are poorly understood with the exception of age, family history, and ethnicity. ${ }^{3-5}$ Exogenous factors may play a role in the etiology of prostate cancer, but there are still no well-established risks. ${ }^{1,6}$ Occupational exposures (e.g., pesticides, metals, diesel exhaust, polycyclic aromatic hydrocarbons, and mineral oils) have been evaluated in relation to prostate cancer in previous studies with mixed findings. ${ }^{6-10} \mathrm{It}$ is speculated that these occupational exposures may be related to prostate cancer risk but further research is necessary to strengthen the evidence. Many of these occupational exposures are commonly found in industries which involve the harvesting and extracting of raw materials from natural resources. ${ }^{11}$ Many of these exposures have also been classified as known or probably carcinogenic to humans by the International Agency for Research on Cancer. Although there is limited physiologic evidence, these occupational exposures may be involved in impacting hormone levels leading to DNA damage and tumor initiation in the prostate. ${ }^{1,7,12}$ As the prostate is controlled by testosterone it is theorized that hormonal imbalances or androgenic stimulation may cause carcinogenesis as androgenic stimulation is important for promoting the growth of both normal and cancerous prostate cells. There is also evidence from human and animal studies that show high estrogen levels may lead to increased prostate cancer risk. ${ }^{7,13-14}$ Androgenic stimulation and higher estrogen levels may be influenced by exposure to occupational, environmental, dietary and lifestyle factors. ${ }^{\text {, 12-14 }}$

The current study utilizes data from a previously reported case-control study in Northeastern Ontario. Previous publications from this study primarily focused on potential risk factors unrelated to occupation, however one publication by Sass-Kortsak et al. addressed occupational factors related to prostate cancer. ${ }^{1,12,15-16}$ The paper reported on multiple potential exposures based on expert assessed cumulative lifetime exposure and identified a strong association for whole body vibrations and prostate 
cancer. Sass-Kortsak et al. also found a significant association for employment in "trades, transport, equipment operators, and related occupations" and prostate cancer, however this was based on very broad occupation groups and longest held job. ${ }^{1}$ Sass-Kortsak et al. did not explore detailed occupations and industries or duration of employment which is necessary for comparison to other studies in the literature. There is a need to build upon existing knowledge by evaluating risk using detailed information on occupation, industry, and exposures.

In Canada, primary industries include agriculture, forestry and logging, fishing and trapping, mining, and oil and gas extraction with a majority of workers being men. ${ }^{11}$ The Northeastern region in the province of Ontario in Canada has a higher number of natural resource based workers than other parts of the country, primarily in the mining and forestry industries. ${ }^{11}$ Major mining industries in Northeastern Ontario include uranium, gold, nickel, copper, and other metal mines. Risk of prostate cancer has not been studied exclusively in natural resource based industry workers, and since exposure levels to known and suspected carcinogens may be higher in these workers as compared to other occupational groups, it is important to conduct additional work. The objective of this study was to investigate potential associations between work in natural resource industries and occupations and the risk of prostate cancer in Northeastern Ontario. This study specifically focused on natural resource based exposures using detailed employment titles, duration of employment, and exposure to occupational agents that have not been examined in previous analyses of the data.

\section{METHODS}

\section{Study Population}

The case control study took place in Northeastern Ontario which represents a majority of the Northern Ontario population $(\sim 500,000)$ and included the regions of Sudbury, Algoma, Cochrane, Timiskaming, 
Parry Sound, Muskoka, Manitoulin, and Sudbury District. The economy in Northern Ontario historically relied on natural resource based industries and these industries still remain as important contributors to economic growth in the region. ${ }^{17}$ The Sudbury region is recognized for its extensive development of copper and nickel mining, smelting, and refining processes and as a result Canada was a world leader in nickel production in the 1900s. Other metal discoveries included gold and silver deposits that spanned across Northeastern Ontario and included the regions of Cobalt, Porcupine Lake, Timmins, and Kirkland Lake. In the 1950s, Elliot Lake in the Algoma District became a booming area for uranium mining. ${ }^{17}$ The forestry and wood industries were primarily sawmill and pulp and paper mills and in 2004 at least one third of Northern Ontario was dependent on the forestry industry. ${ }^{18}$ Farming and agriculture has continued in multiple regions across Northern Ontario, including Timiskaming, Cochrane, Sudbury, Parry Sound, Algoma, and Manitoulin and production is expected to increase by 20 to $50 \%$ in the coming years. $^{19}$

As this was a secondary analysis of a previously conducted study, the detailed description of the study sample can be found in previously published papers. ${ }^{1,16,20-21}$ Briefly, incident prostate cancer cases were men between the ages of 45 to 85 years, who resided in Northeastern Ontario, and were identified in the Ontario Cancer Registry with primary histologically confirmed prostate cancer diagnosed between January 1995 and December 1998. Controls were randomly selected from the Northeastern Ontario population using residential telephone listings and were frequency matched 2:1 to cases based on 5 year age groups. Participation rates in the study were $73.6 \%$ for cases and $47.5 \%$ for controls. ${ }^{20}$

\section{Exposure Classification}

Consenting participants were mailed a questionnaire followed by telephone contact by trained interviewers. The questionnaire included sections on demographics, general health, smoking, diet, 
physical activity, family, and occupational history. Interviewers utilized the questionnaire to assess detailed lifetime job histories based on jobs held for 1 or more years. Each job history included information on job titles, employer name and type, job duties, work description, and work environment. ${ }^{1,16,20}$ An occupational hygienist coded job descriptions (four digit) using the 1991 Standard Occupation Classification (SOC91) and 1980 Standard Industry Classification (SIC80) systems. ${ }^{22-23}$ Industries and occupations were then broadly grouped into 58 new occupation categories and 38 new industry categories based on their SOC91 and SIC $80 \operatorname{codes}^{22-23}$ and similarities in job tasks and potential exposures. For this current analysis only industries and occupations related to natural resources were included, resulting in 10 industry and 9 occupation categories (Table 1, Supplementary File). Ever employment was defined as any job held for at least one year with corresponding SOC91 and SIC80 codes. Duration of employment was examined by categorizing employment as less than 10 years and 10 years or greater to assess short term and long term exposures. Potential exposure response trends in duration of employment and prostate cancer risk were also examined using tertile categories, based on the distribution of controls in each industry and occupation. Self-reported data were also used to assess ever versus never exposure in cases and controls based on participant responses to occupational agents listed in the questionnaire.

\section{Statistical Analysis}

Unconditional logistic regression models were used to assess if duration of employment in different natural resource industries and occupations, and if relevant occupational exposures, were associated with prostate cancer. All cases or controls not employed in the specific category being evaluated served as the non-exposed referent category. Only categories with at least 5 cases or 5 controls were analyzed. SAS version 9.2 was used for statistical modelling. ${ }^{24}$ Odds ratios with $95 \%$ confidence intervals above 1 were considered statistically significant. Adjustments were made for five year age groups and family 
history of prostate cancer. Ethnicity was not included as a covariate as the majority of participants were Caucasian. ${ }^{1,16,20}$ Education and income were considered as potential confounders however these factors did not present any significant changes in the odds ratios. History of venereal disease and cumulative lifetime occupational physical activity were found to be significant in previous publications, but adjusting for these variables resulted in no significant changes in our estimates. ${ }^{1,20}$ Exposure response trends were evaluated using logistic regression by treating the ordinal variables as continuous in the model to calculate the $p$-values for trend. Additionally, industries and occupations in this study that were previously associated with prostate cancer in the literature (i.e., farming and agriculture) were also reported and discussed.

\section{RESULTS}

Cases and controls were of similar age (mean 68.2 years, SD=7.5) (Table 1). Of the potential covariates examined, only family history of prostate cancer was significantly associated with prostate cancer risk (OR 2.85, 95\% Cl 2.13-3.83). All subsequent analyses by industry group (Table 2 ) and occupation group (Table 3) were adjusted for both age and family history. 
Table 1. Selected characteristics of cases and controls in the Northeastern Ontario Prostate Cancer Study

\begin{tabular}{|c|c|c|c|}
\hline & Cases $(\mathrm{N}=749)(\%)$ & Controls ( $\mathrm{N}=1608)(\%)$ & $\mathrm{OR}^{*}(95 \%)$ \\
\hline \multicolumn{4}{|l|}{ AGE GROUPS (YEARS) } \\
\hline 45 to $<50$ & $8(1.1)$ & $18(1.1)$ & \\
\hline 50 to $<55$ & $25(3.3)$ & $68(4.2)$ & \\
\hline 55 to $<60$ & $48(6.4)$ & $135(8.4)$ & \\
\hline 60 to $<65$ & $133(17.7)$ & $271(16.8)$ & \\
\hline 65 to $<70$ & $220(29.0)$ & $439(27.3)$ & \\
\hline 70 to $<75$ & $177(23.63)$ & 381 (23.69) & \\
\hline 75 to $<80$ & $106(14.1)$ & $198(12.3)$ & \\
\hline 80 to $<85$ & $31(4.1)$ & 95 (5.9) & \\
\hline Missing & $1(0.1)$ & $3(0.2)$ & \\
\hline \multicolumn{4}{|c|}{ FAMILY HISTORY OF PROSTATE CANCER } \\
\hline Yes & $108(14.4)$ & $90(5.6)$ & $2.83(2.10-3.80)$ \\
\hline No & $641(85.6)$ & $1519(94.4)$ & Ref \\
\hline \multicolumn{4}{|l|}{ ETHNICITY } \\
\hline English Canadian & $402(53.7)$ & $901(56.0)$ & $0.98(0.79-1.22)$ \\
\hline French Canadian & $173(23.1)$ & $332(20.7)$ & $1.15(0.89-1.50)$ \\
\hline Aboriginal (Native) & $7(0.9)$ & $6(0.4)$ & $2.69(0.89-8.18)$ \\
\hline Other & $165(22.0)$ & $361(22.5)$ & Ref \\
\hline Missing & $2(0.3)$ & $8(0.5)$ & $0.56(0.12-2.67)$ \\
\hline \multicolumn{4}{|l|}{ EDUCATION } \\
\hline No school & $2(0.3)$ & $3(0.2)$ & $1.29(0.21-7.87)$ \\
\hline Some elementary & $99(13.2)$ & $188(11.7)$ & Ref \\
\hline Elementary & $158(21.1)$ & $341(21.2)$ & $0.87(0.64-1.18)$ \\
\hline Some high school & $226(30.2)$ & $415(25.8)$ & $1.04(0.77-1.39)$ \\
\hline Finished high school & $138(18.4)$ & $319(19.8)$ & $0.83(0.60-1.14)$ \\
\hline Some college/university & $32(4.3)$ & $84(5.2)$ & $0.73(0.45-1.17)$ \\
\hline Finished college/university & $67(9.0)$ & 189 (11.8) & $0.68(0.47-0.99)$ \\
\hline Post graduate & $17(2.3)$ & $43(2.7)$ & $0.78(0.42-1.44)$ \\
\hline Professional & $5(0.7)$ & $17(1.1)$ & $0.56(0.20-1.57)$ \\
\hline Missing & $5(0.7)$ & $10(0.6)$ & $1.03(0.34-3.2)$ \\
\hline \multicolumn{4}{|l|}{ TOTAL FAMILY INCOME } \\
\hline$<\$ 20,000$ & $94(12.6)$ & $183(11.4)$ & Ref \\
\hline$\$ 20,000-\$ 39,000$ & 269 (35.9) & $517(32.1)$ & $0.97(0.72-1.30)$ \\
\hline$\$ 40,000-59,000$ & $178(23.8)$ & $455(28.3)$ & $0.72(0.52-0.98)$ \\
\hline$\$ 60,000-\$ 79,000$ & $87(11.6)$ & $171(10.6)$ & $0.97(0.66-1.41)$ \\
\hline$\$ 80,000-\$ 99,999$ & $28(3.7)$ & $55(3.4)$ & $0.97(0.57-1.65)$ \\
\hline$>\$ 100,000$ & $21(2.8)$ & $59(3.7)$ & $0.69(0.39-1.21)$ \\
\hline Missing & $72(9.6)$ & $168(10.5)$ & $0.80(0.55-1.16)$ \\
\hline
\end{tabular}


A non-significantly elevated risk was observed for employment in the agricultural industry (agriculture and farm work, and services incidental to agriculture) (OR 1.15, 95\% $\mathrm{Cl} 0.96-1.38)$. Fishing and trapping industry work demonstrated an elevated risk (OR 3.32, 95\% $\mathrm{Cl}$ 1.14-9.67), which was highest for those employed for $<10$ years (OR 4.49, 95\% Cl 1.05-19.17). For employment in the forestry and logging industry, there was an elevated risk (OR $1.87,95 \% \mathrm{Cl} 1.32-2.73$ ), which was highest for employment $\geq 10$ years (OR 2.55, 95\% Cl 1.59-4.11) and a significant trend was observed with duration of employment $\left(p_{\text {trend }}<0.0001\right)$. An elevated risk was observed for employment in the wood products industry (OR 1.45, $95 \% \mathrm{Cl} 1.07-1.97)$, which somewhat increased with $\geq 10$ years duration of employment (OR $1.73,95 \% \mathrm{Cl}$ 1.08-1.90). A significant increasing trend was also observed for employment in the wood products industry $\left(p_{\text {trend }}=0.011\right)$. There was an elevated risk for employment in the paper and allied products industry (OR $1.43,95 \% \mathrm{Cl} 1.03-2.00)$, especially with $\geq 10$ years of employment (OR $1.98,95 \% \mathrm{Cl} 1.29$ 3.02) and a significant trend was observed $\left(p_{\text {trend }}=0.007\right)$. For the mining industry, there was an elevated risk for employment in other services incidental to mining (OR 2.09, 95\% Cl 1.18-3.72) and a nonsignificantly elevated risk with $\geq 10$ years of employment duration (OR $2.50,95 \% \mathrm{Cl} 0.90-7.00$ ). A significant trend for duration of employment was also observed for these mining related workers $\left(p_{\text {trend }}=0.004\right)$. A non-significantly elevated risk was observed for employment in the quarrying industry (OR 3.33, 95\% $\mathrm{Cl}$ 0.76-14.54) however, due to the small sample size, a trend analysis could not be performed. There were no strong associations observed for employment in metal mining, non-metal mining, and petroleum and coal mining industries. 
Table 2. Odds ratios and $95 \%$ Cls for associations between prostate cancer and employment in natural resource based industries

\begin{tabular}{|c|c|c|c|c|c|c|}
\hline \multirow[b]{3}{*}{ Industry Groups } & \multicolumn{6}{|c|}{ Duration } \\
\hline & \multirow[b]{2}{*}{$\begin{array}{l}\text { Cases/ } \\
\text { Controls }\end{array}$} & \multirow[b]{2}{*}{ OR* $(95 \% \mathrm{Cl})$} & \multirow[b]{2}{*}{$\begin{array}{l}\text { Cases/ } \\
\text { Controls }\end{array}$} & \multicolumn{2}{|l|}{$>0$ to $<10$ Years } & \multirow{2}{*}{$\begin{array}{l}\geq 10 \text { Years } \\
\text { OR* }(95 \% \mathrm{Cl})\end{array}$} \\
\hline & & & & OR* $(95 \% \mathrm{Cl})$ & $\begin{array}{l}\text { Cases/ } \\
\text { Controls }\end{array}$ & \\
\hline $\begin{array}{l}\text { Agriculture and Farm Work, } \\
\text { Services Incidental to Agriculture }\end{array}$ & $276 / 531$ & $1.15(0.96-1.38)$ & $92 / 159$ & $1.29(0.97-1.71)$ & $184 / 372$ & $1.10(0.89-1.35)$ \\
\hline Forestry and Logging & $60 / 68$ & $1.90(1.32-2.73)$ & $33 / 45$ & $1.51(0.94-2.40)$ & $27 / 23$ & $2.70(1.52-4.79)$ \\
\hline Fishing and Trapping & $8 / 6$ & $3.32(1.14-9.67)$ & $5 / 3$ & 4.49 (1.05-19.17) & $3 / 3$ & $2.25(0.45-11.22)$ \\
\hline Metal Mining & $202 / 460$ & $0.96(0.79-1.17)$ & $71 / 137$ & $1.15(0.85-1.57)$ & $131 / 323$ & $0.88(0.85-1.57)$ \\
\hline Non Metal Mining & $12 / 28$ & $0.90(0.45-1.80)$ & $8 / 21$ & $0.77(0.33-1.76)$ & $4 / 7$ & $1.34(0.39-4.66)$ \\
\hline Quarrying & $5 / 3$ & $3.33(0.76-14.54)$ & $3 / 3$ & $2.08(0.40-10.68)$ & $2 / 0$ & -- \\
\hline Petroleum and Coal & $3 / 11$ & $0.62(0.17-2.24)$ & $3 / 8$ & $0.80(0.21-3.07)$ & $0 / 3$ & -- \\
\hline Other Services Incidental to Mining & $24 / 25$ & $2.09(1.18-3.72)$ & $16 / 18$ & $1.94(0.97-3.86)$ & $8 / 7$ & $2.50(0.90-7.00)$ \\
\hline Wood Products & $79 / 120$ & 1.45 (1.07-1.97) & $46 / 77$ & $1.30(0.88-1.90)$ & $33 / 43$ & $1.73(1.08-1.90)$ \\
\hline Paper and Allied Products & $62 / 99$ & $1.43(1.03-2.00)$ & $20 / 49$ & $0.90(0.53-1.53)$ & $42 / 50$ & $1.98(1.29-3.02)$ \\
\hline
\end{tabular}

At an occupation level, there was an elevated risk for general farm workers and labourers (OR 1.23, 95\%

$\mathrm{Cl} 1.02-1.49$ ) which was higher for those employed $<10$ years (OR $1.42,95 \% \mathrm{Cl} 1.06-1.91$ ). No significant trends were identified for duration of employment in agriculture and farm work. A non-significantly elevated risk was found for occupations related to fishing, trapping, and hunting (OR $3.03,95 \% \mathrm{Cl} 0.91$ 10.06). No trend analysis was performed on this group due to its small sample size. Elevated risks were also observed for forestry and logging occupations (OR $1.7195 \% \mathrm{Cl}$ 1.24-2.35), which was highest for duration of employment of $\geq 10$ years (OR $2.55,95 \% \mathrm{Cl} 1.58-4.11$ ). A significant trend with duration of employment was observed for forestry and logging ( $\left.p_{\text {trend }}<0.0001\right)$. For wood processing and making occupations, the risk was not elevated (OR 1.16, 95\% Cl 0.86-1.57). An elevated risk was observed for men employed in wood processing and making occupations within the wood industry (OR $1.64,95 \% \mathrm{Cl}$ 1.06-2.54), although an excess was also observed among non-wood-related occupations in the same industry (OR 1.45, 95\% $\mathrm{Cl}$ 1.07-1.97). There were no strong associations observed for employment in pulp and papermaking occupations and mining related occupations. 
Table 3. Odds ratios and $95 \% \mathrm{Cls}$ for associations between prostate cancer and employment in natural resource based occupations

\begin{tabular}{|c|c|c|c|c|c|c|}
\hline \multirow[b]{3}{*}{ Occupation Groups } & \multicolumn{6}{|c|}{ Duration } \\
\hline & & & & $>0$ to $<10$ Years & & $\geq 10$ Years \\
\hline & $\begin{array}{l}\text { Cases/ } \\
\text { Controls }\end{array}$ & OR* $(95 \% \mathrm{Cl})$ & $\begin{array}{l}\text { Cases/ } \\
\text { Controls }\end{array}$ & OR* $(95 \% \mathrm{Cl})$ & $\begin{array}{l}\text { Cases/ } \\
\text { Controls }\end{array}$ & OR* $(95 \% \mathrm{Cl})$ \\
\hline $\begin{array}{l}\text { Farmers, Farm and Agriculture } \\
\text { Managers }\end{array}$ & $48 / 128$ & $0.74(0.52-1.05)$ & $12 / 39$ & $0.59(0.30-1.14)$ & $36 / 89$ & $0.81(0.54-1.22)$ \\
\hline $\begin{array}{l}\text { General Farm Workers and } \\
\text { Labourers }\end{array}$ & $243 / 443$ & $1.23(1.02-1.49)$ & $84 / 134$ & $1.42(1.06-1.91)$ & $159 / 309$ & $1.15(0.92-1.44)$ \\
\hline $\begin{array}{l}\text { Agriculturists and Related } \\
\text { Specialists }\end{array}$ & $3 / 8$ & $0.79(0.21-3.03)$ & $2 / 0$ & -- & $1 / 8$ & $0.25(0.03-2.08)$ \\
\hline Forestry and Logging & $75 / 97$ & $1.71(1.24-2.35)$ & $37 / 63$ & $1.26(0.83-1.93)$ & $38 / 34$ & $2.55(1.59-4.11)$ \\
\hline Fishing, Trapping, and Hunting & $6 / 5$ & $3.02(0.91-10.03)$ & $4 / 3$ & $3.65(0.80-16.67)$ & $2 / 2$ & $2.18(0.31-15.55)$ \\
\hline Mining, Quarrying, Oil, and Gas & $149 / 297$ & $1.12(0.89-1.39)$ & $64 / 115$ & $1.21(0.88-1.68)$ & $85 / 182$ & $1.05(0.80-1.39)$ \\
\hline Wood Processing and Making & $76 / 139$ & $1.16(0.86-1.57)$ & $27 / 60$ & $0.94(0.58-1.50)$ & $49 / 79$ & $1.33(0.92-1.93)$ \\
\hline Pulp and Papermaking & $28 / 47$ & $1.32(0.82-2.14)$ & $18 / 34$ & $1.17(0.65-2.09)$ & $10 / 13$ & $1.75(0.76-4.05)$ \\
\hline $\begin{array}{l}\text { Primary Production and } \\
\text { Manufacturing Managers }\end{array}$ & $21 / 44$ & $1.05(0.61-1.78)$ & $5 / 14$ & $0.77(0.27-1.16)$ & $16 / 30$ & $1.18(0.63-2.20)$ \\
\hline
\end{tabular}

For self-reported occupational exposures, a number of exposures presented non-significantly elevated odds ratios (Table 2, Supplementary File).

\section{DISCUSSION}

This study reports on multiple strong associations and trends between employment in natural resource industries and occupations and prostate cancer risk. These results provide additional evidence on the potential occupational risk factors for prostate cancer in an area where natural resource-based employment is concentrated.

In our study, a small overall increase among agricultural workers was observed. The excess appeared to be restricted to farm workers and labourers with the highest risk among those employed for less than 10 years. Previous studies have been conducted to investigate the relationship between prostate cancer 
and agriculture related occupations with inconsistent findings. ${ }^{25-29}$ Prostate cancer in relation to agriculture and farming occupations has been more commonly studied than other occupations with most studies focused on pesticide exposures. A meta-analysis that looked at the association between farming and prostate cancer found a nearly four-fold increased risk overall (OR $3.83,95 \% \mathrm{Cl} 1.96-7.48$ ) but found an inverse association between pesticide exposure and prostate cancer. ${ }^{26} \mathrm{~A}$ recently published study of prostate cancer in a rural population in Saskatchewan, Canada identified that combined workplace exposure to insecticides and fungicides was significantly associated with prostate cancer (OR 2.23, 95\% Cl 1.15-4.33). ${ }^{30}$ Specific organophosphate insecticides such as fonofos, malathion, terbufos, and aldrin have been associated with aggressive prostate cancer. ${ }^{31}$ Other studies have found pesticide exposure from farming occupations to be a possible risk factor for prostate cancer. ${ }^{7,32}$ Specifically, pesticide applicators with exposure to chlorinated pesticides and methyl bromide were linked to increased prostate cancer risk $(p=0.005) \cdot{ }^{33}$ There is evidence that insecticides, herbicides and metal (e.g. cadmium) exposures are linked to prostate cancer risk. ${ }^{30,34}$

In 2013, a report was published on the use of 2,4,5-Trichlorophenoxyacetic acid (2,4,5-T) herbicide in Ontario and the possible health effects. ${ }^{35}$ From the early 1940 s to late 1970 s, chemical agents like $2,4,5$ T were utilized to aid in the re-establishment of the conifer forest in Northern Ontario. This herbicide is classified as a possible carcinogen (group 2B) by IARC (likely due to its contamination with 2,3,7,8-TCDD, a carcinogenic dioxin) and is linked to prostate cancer with limited evidence. ${ }^{35}$ Given that the time period of occupational use of this herbicide overlaps with the work records of the study cases, it is likely that Northern Ontario agricultural workers were exposed to 2,4,5 $\mathrm{T}$ and the associated dioxin contaminants. The interpretation of these important findings across different studies continues to be inconsistent. But the existence of an excess risk in agriculture and farming related occupations demonstrates the need for further research. 
Employment in fishing and trapping was also found to be associated with prostate cancer risk in this study, however the number of exposed workers was quite small and the confidence intervals were wide. The strongest associations were observed for work $<10$ years. It is unclear what type of exposures in fishing and trapping work could contribute to the risk of prostate cancer.

Employment in forestry and logging in this case control study was found to be associated with prostate cancer, especially among those employed for greater than 10 years. Based on an analysis of tertile categories, employment in forestry and logging at both an occupation and industry level demonstrated a significant trend with duration of employment. Employment in this occupation included work as forestry and logging professionals, operators, and labourers. Forestry and logging operations involve use of heavy machinery and equipment that may lead to exposure of diesel exhaust, wood dust and whole body vibrations. ${ }^{1,36}$ There are few studies that examine forestry and logging related exposures, and currently there are no studies that examine prostate cancer. It is also unclear how the interaction of these exposures contributes to the risk of prostate cancer.

Employment in the wood products industry was also associated with prostate cancer and the risk increased with $\geq 10$ years duration. An excess was observed among men in both wood-related and nonwood-related occupations within the wood products industry. This may indicate that the risk in the wood products industries are due to exposures unique to that industry, rather than woodworking itself. The wood industries include sawmills and planing mills, as well as other wood product industries where there may be exposure to the volatile components of fresh wood as well as pesticides, such as fungicides and wood preservatives. Employment in the paper and allied products industry was also associated with prostate cancer, especially with $\geq 10$ years duration and a significant trend was observed with duration of employment. At an occupational level, the specific group of pulp and papermaking 
occupations had no increased risk. Primarily, exposure in the wood products and paper industries include wood dust and wood pulping and papermaking chemicals such as sulphates and chlorine compounds. ${ }^{37-39}$ These chemical exposures in forestry, wood products, and paper industries may act as endocrine disruptors in the human body.${ }^{39}$ These disruptors could influence hormone levels and play a role in prostate cancer etiology. ${ }^{7}$

At an industry level, metal mining, non-metal mining, quarrying, and petroleum and oil industries were not found to be associated with prostate cancer. However, employment in other services incidental to mining was found to be associated with prostate cancer and increased with duration. This group included contract drilling and any other services related to mining. It is unclear as to what other specific services were included in this group but there may be a heterogeneous combination of mining jobs. At an occupation level, mining related work was not found to be associated with prostate cancer. Employment in mining can result in many different exposures depending on the type of mining (surface vs. underground) and the substance being mined. Other studies have identified multiple exposures in mining including but not limited to metals, dust, diesel exhaust, whole body vibrations, radiation, shift work, and other chemicals. ${ }^{40-41}$

As a part of the original study, participants were asked in the study questionnaire to report if they were ever exposed to listed occupational agents. Based on these self-reported data, an elevated risk was observed for sun exposure and non-significantly elevated risks were observed for exposure to diesel exhaust, pesticides, combustion products, lubricating oils, and noise. (Table 2, Supplementary File). Although the ever/never exposure classifications represents unadjusted associations and are selfreported, these findings may provide further evidence on specific agents related to natural resource based work. 
This study has a number of limitations based on data collection and approach. The response rate of cases and controls were lower than desired and recall bias may be a factor with questionnaires provided to both cases and controls. ${ }^{16,20}$ Not unexpectedly, the response rate of controls was much lower than for cases such that selection bias could occur while also making the results less generalizable to the population. Some industry and occupation categories also presented small sample sizes. This study relied on job titles and even though similar exposure jobs were grouped together there is still room for heterogeneity as significant findings in sub-sector groups may be diluted and not detected in these broader level categories. There was also no information collected on the stage or aggressiveness of the tumors in cases which may have been useful to examine occupational exposure differences by aggressiveness of prostate cancer. This study also has a number of strengths. The availability of lifetime job histories provided useful detailed job information for this specific region with a high prevalence of natural resource industry work. This study also collected data on three known risk factors for prostate cancer, age, family history, and ethnicity, which have not always been available in other prostate cancer studies.

\section{CONCLUSION}

This study offers additional evidence that employment in natural resource based industries and occupations may be associated with a higher risk of prostate cancer. Specifically, long-term employment in forestry, logging, wood, and the paper industry was observed to be associated with increased risks of prostate cancer. Additional elevated risks were observed for other natural resource based industries and occupations. Although there were no clear occupational agents identified, workers in these industries are exposed to multiple known and suspected carcinogens that are important to assess in further analyses. Use of detailed exposure data in larger study populations is needed to further evaluate the 
potential role of occupational exposures in the development of prostate cancer.

\section{ACKNOWLEDGEMENTS}

Jeavana Sritharan is supported through funding from the Canadian Cancer Society. The Occupational Cancer Research Centre is funded by the Canadian Cancer Society Research Institute, the Ontario Ministry of Labour, and Cancer Care Ontario. Manisha Pahwa is also thanked for her contribution to data analysis and manuscript preparation.

COMPETING INTERESTS: None 


\section{REFERENCES}

1. Sass-Kortsak MA, Purdham JT, Kreiger N, et al. Occupational risk factors for prostate cancer. American Journal of Industrial Medicine 2007;50:568-576.

2. Demichelis F \& Stanford JL. Genetic predisposition to prostate cancer: update and future perspectives. Urologic Oncology 2014, Article in Press.

3. Hsing AW \& Chokkalingam AP. Prostate cancer epidemiology. Frontiers in Bioscience: a journal and virtual library 2006;1(11):1388-413.

4. Plata BA \& Concepcion MT. Prostate cancer epidemiology. Archivos Espanoles De Urologia 2014;67(5):373-82.

5. Bashir, MN. Epidemiology of prostate cancer. Asian Pacific Journal of Cancer Prevention 2015;16(13):5137-5141.

6. Parent ME \& Siemiatycki J. Occupation and prostate cancer. Epidemiologic Reviews 2001;23(1):138-43.

7. Parent ME, Desy M \& Siemiatycki J. Does exposure to agricultural chemicals increase the risk of prostate cancer among farmers? McGill Journal of Medicine 2009;12(1):70-77.

8. Nelles JL, Hu W \& Prins GS. Estrogen action and prostate cancer. Expert Review of Endocrinology \& Metabolism 2011;6(3):437-451.

9. Boers D, Zeegers MPA, Swaen GM, et al. The influence of occupational exposure to pesticides, polycyclic aromatic hydrocarbons, diesel exhaust, metal dust, metal fumes, and mineral oil on prostate cancer: a prospective cohort study. Occupational and Environmental Medicine 2005;62:531-537.

10. Doolan G, Benke G \& Giles G. An update on occupation and prostate cancer. Asian Pacific Journal of Cancer Prevention 2014;15(2):501-16. 
11. Statistics Canada. (2006). Primary industries. Ottawa: Statistics Canada.

http://www41.statcan.gc.ca/2006/1664/ceb1664_000-eng.htm (accessed September 2015).

12. Van Maele-Fabry G \& Willems JL. Occupation related pesticide exposure and cancer of the prostate: a meta-analysis. Occupational and Environmental Medicine 2003;60(9):634-42.

13. -National Cancer Institute. Hormone therapy for prostate cancer. U.S. Department of Health and Human Sciences. http://www.cancer.gov/types/prostate/prostate-hormone-therapy-factsheet\#q2

14. -Golden RJ, Noller KL, Titus-Ernstoff L, et al. Environmental endocrine modulators and human health: an assessment of the biological evidence. Critical Reviews in Toxicology, 1998: 28: 109227.

15. International Agency for Research on Cancer. (2013). IARC monographs on the evaluation of carcinogenic risks to humans. http://monographs.iarc.fr/ (accessed September 2015).

16. Lightfoot N, Kreiger N, Sass-Kortsak A, et al. Prostate cancer risk. Medical history, sexual, and hormonal factors. Annals of Epidemiology 2000;10(7):470.

17. Industry Canada. (2011). Archived - final evaluation for the Northern Ontario development program. Ottawa: Government of Canada. https://www.ic.gc.ca/eic/site/ae-ve.nsf/eng/03336.html\#ftn3 (accessed November 2015).

18. Bollman RD, Beshiri R \& Mitura V. (2006). Northern Ontario's communities: economic diversification, specialization, and growth. Ottawa: Statistics Canada. http://www.statcan.gc.ca/pub/21-601-m/21-601-m2006082-eng.pdf (accessed November 2015).

19. Caldwell E. (2011). Building capacity for northern Ontario agriculture. Sault Ste. Marie: Innovation Centre. http://www.fonom.org/sites/default/files/4\%20May\%209\%20\%201020am\%20RAIN.pdf (accessed November 2015). 
20. Lightfoot N, Conlon $\mathrm{M}$, Kreiger N, et al. Medical history, sexual, and maturational factors and prostate cancer risk. Annals of Epidemiology 2004;14(9):655-662.

21. Darlington GA, Kreiger N, Lightfoot N, et al. Prostate cancer risk and diet, recreational physical activity and cigarette smoking. Chronic Diseases in Canada 2007;27(4):145-153.

22. Statistics Canada. (1980). Standard industrial classification. Ottawa: Minister of Supply and Services.

http://www23.statcan.gc.ca/imdb/p3VD.pl?Function=getVD\&TVD=53446 (accessed August 2015).

23. Statistics Canada. (1993). Standard occupational classification. Ottawa: Minister of Industry, Science and Technology. http://www23.statcan.gc.ca/imdb/p3VD.pl?Function=getVD\&TVD=143375 (accessed August 2015).

24. SAS Institute Inc. (2015). SAS 9.4. Cary, USA: SAS. http://www.sas.com/en_ca/home.html (accessed October 2015).

25. Jones RR, Barone-Adesi F, Koutros S, et al. Incidence of solid tumours among pesticide applicators exposed to the organophosphate insecticide diazinon in the agricultural health study: an updated analysis. Occupational and Environmental Medicine 2015;72(7):496-503.

26. Ragin C, Davis-Reyes B, Tadesse H, et al. Farming, reported pesticide use, and prostate cancer. American Journal of Men's Health 2013;7(2):102-109.

27. Barry KH, Koutros S, Lubin JH, et al. Methyl bromide exposure and cancer risk in the agricultural health study. Cancer Causes Control 2012;23(6):807-818.

28. Fragar L, Depczynski J \& Lower T. Mortality patterns of Australian male farmers and farm managers. Australian Journal of Rural Health 2011;19(4):179-184. 
29. Band PR, Abanto Z, Bert J, et al. Prostate cancer risk and exposure to pesticides in British Columbia farmers. Prostate 2011,71(2):168-183.

30. Sharma M, Lawson JA, Kanthan R, et al. Journal of Rural Health 2015, 10.1111/jrh.12137.

31. Koutros S, Freeman LEB, Lubin JH, et al. (2013) Risk of total and aggressive prostate cancer and pesticide use in the agricultural health study. American Journal of Epidemiology, 177(1): 59-74.

32. Van Maele-Fabry G, Libotte V, Willems J, et al. Review and meta-analysis of risk estimates for prostate cancer in pesticide manufacturing workers. Cancer Causes Control 2006;17(4):353-373.

33. Alavanja MCR, Samanic C, Dosemeci M, et al. (2003) Use of agricultural pesticides and prostate cancer risk in the agricultural health study cohort. American Journal of Epidemiology, 157(9): 800-814.

34. Sahmoun AE, Case LD, Jackson SA, et al. Cadmium and prostate cancer: a critical epidemiologic analysis. Cancer Investigation 2005;23(3):256-263.

35. Ritter L, Blair A, Kerkvliet NI, et al. Report of the independent fact-finding panel on herbicide 2,4,5-T: final report. Government of Ontario 2013 April. http://www.ontario.ca/page/contactherbicide-245-t (accessed 25 November 2015).

36. Magagnotti N, Picchi G, Gianfranco S, et al. Exposure of mobile chipper operators to diesel exhaust. The Annals of Occupational Hygiene 2013;52:217-226.

37. Statistics Canada. (2010). ARCHIVED - chronic diseases in Canada. Ottawa: Public Health Agency of Canada. http://www.phac-aspc.gc.ca/publicat/hpcdp-pspmc/30-4/preface-eng.php (accessed September 2015).

38. Vallieres E, Pintos J, Parent ME, et al. Occupational exposure to wood dust and risk of lung cancer in two population-based case-control studies in Montreal, Canada. Environmental Health 2015;14:1. 
39. Villeneuve S, Cry D, Lynge E, et al. Occupation and occupational exposure to endocrine disrupting chemicals in male breast cancer: a case-control study in Europe. Occupational and Environmental Medicine 2010;67(12):837-844.

40. Peters S, Reid A, Fritschi L, et al. Cancer incidence and mortality among underground and surface goldminers in Western Australia. British Journal of Cancer 2013;108(9):1879-1882.

41. Huvinen M \& Pukkala E. Cancer incidence among Finnish ferrochromium and stainless steel production workers in 1967-2011: a cohort study. BMJ Open 2013;3(11):e003819. 


\section{Contributorship Statement}

The corresponding author, Jeavana Sritharan, is the main contributor to this secondary analysis and was the main contributor in planning and designing the research analysis, conducting the analysis, and reporting and interpreting the work into a manuscript. Dr. Paul A Demers, Dr. Shelley Harris, and Dr. Donald Cole contributed to the planning and design of the analysis, reporting and interpretation of the work, and review of the analysis and manuscript. Dr. Nancy Kreiger, Dr. Andrea Sass-Kortsak and Dr. Nancy Lightfoot contributed to the planning, conducting, and reporting of the original case-control study (primary analysis) and were a part of the planning of analysis, reporting and interpretation of the work, and manuscript preparation. Manisha Pahwa is mentioned in the acknowledgements section for her contribution to planning the analysis and manuscript preparation.

\section{Ethics Statement}

This research received ethics review and approval from the Laurentian Hospital Research Ethics Board in Sudbury, Ontario, Canada prior to 1995 when the study was initiated. Consent was obtained from cases and controls prior to participation in the study.

\section{Previous publication related to this manuscript}

Sass-Kortsak MA, Purdham JT, Kreiger N, et al. Occupational risk factors for prostate cancer. American Journal of Industrial Medicine 2007;50: 568-576. 